\title{
Genetic diversity and structure of circumtropical almaco jack Seriola rivoliana : tool for conservation and management.
}

\author{
Mendoza-portillo Verónica ${ }^{1}$, Galván-tirado Carolina ${ }^{2}$, Portnoy David S. ${ }^{3}$, \\ Valenzuela-quiñonez Fausto 4, Domínguez Domínguez Omar 5, 6, Durand Jean-Dominique 7, \\ Pérez Urbiola Pérez Urbiola Juan Juan Carlos ${ }^{8}$, García-de León Francisco J. 1, *
}

${ }^{1}$ Laboratorio de Genética para la Conservación, Centro de Investigaciones Biológicas del Noroeste La Paz Baja California Sur ,México

2 CONACYT-Universidad Autónoma de Baja California Sur La Paz Baja California Sur ,México

${ }^{3}$ Marine Genomics Laboratory, Department of Life Sciences Texas A\&M University Corpus Christi

Texas ,United States of America

${ }^{4}$ CONACYT-Centro de Investigaciones Biológicas del Noroeste La Paz Baja California Sur ,México

${ }^{5}$ Laboratorio de Biología Acuática, Facultad de Biología, Universidad Michoacana de San Nicolás de

Hidalgo Morelia Michoacán ,México

${ }^{6}$ Instituto Nacional de Biodiversidad Quito ,Ecuador

7 MARBECUniversité Montpellier-IRD-Ifremer-CNRS ,France

${ }^{8}$ Centro de Investigaciones Biológicas del Noroeste La Paz Baja California Sur ,México

* Corresponding author : García-de León Francisco J, email address : fgarciadl@cibnor.mx

\begin{abstract}
:
The almaco jack Seriola rivoliana is a circumtropical pelagic fish of importance both in commercial fisheries and aquaculture. To understand levels of genetic diversity within and among populations in the wild, population genetic structure and the relative magnitude of migration were assessed with mtDNA sequence data and SNPs from individuals sampled from locations in the Pacific and Atlantic Oceans. A total of 25 variable sites of $\mathrm{COI}$ and 3,678 neutral SNPs were recovered. Three genetic groups were identified with both marker types distributed in different oceanic regions: Pacific-1 in central Pacific, Pacific-2 in eastern Pacific and Atlantic in western Atlantic. However, analysis of SNP identified a fourth population in Pacific coast of Baja California Sur, Mexico (Pacific-3), while mtDNA did not. This mitonuclear discordance is likely explained by a recently diverged Pacific-3 population. In addition, two mtDNA haplogroups were found within the western Atlantic, likely indicating that the species came into the Atlantic from the Indian with historical gene flow from the eastern Pacific. Relative gene flow among ocean basins was low with $r m<0.2$, while in the eastern Pacific was asymmetric, and higher from south to north ( $r$ $\mathrm{m}>0.79$ ). The results reflect the importance of assessing genetic structure and gene flow of natural populations for the purposes of sustainable management.
\end{abstract}

Keywords : Population genomics, Atlantic Ocean, Pacific Ocean, conservation, pelagic fish, gene flow 
This study was supported by Programa de Fomento a la Productividad Pesquera y Acuícola, Instituto Nacional de Pesca-Secretaría de Agricultura, Ganadería, desarrollo Rural, Pesca y Alimentación (INAPESCA-SAGARPA), Number: 2505161165 and CONACYT (CONACYT-CB-2014-240875). 


\section{INTRODUCTION}

Studies of genetic diversity in marine fishes are valuable for conservation and management, and their incorporation into fishery science has become common (Bernatchez et al., 2017). The Food and Agriculture Organization of the United Nations (FAO) has promoted the integration of genetic information into management programs, including aquaculture and commercial fisheries, not only to define unit stocks for management but also to promote conservation of aquatic genetic resources (FAO, 2018). In Mexico, the Program for the Promotion of Fisheries and Aquaculture Productivity promotes genetic studies of commercially important species such as jacks (family Carangidae) in the genus Seriola (SAGARPA, 2017).

Worldwide, jacks in the genus Seriola are important commercially, particularly in the aquaculture industry due to their high value, estimated at $\$ 1.3$ billion (USD) annually worldwide (Purcell et al., 2015). Since the nineties, the almaco jack, Seriola rivoliana Valenciennes 1833 has increased in commercial importance and has been identified as a species with high potential for aquaculture due to its rapid growth, ease of culture, excellent meat quality and value in the international market (Roo et al., 2010, 2014; Sicuro and Luzzana, 2016). Strategies for its cultivation have been implemented in the United States, Mexico, Ecuador and Spain (Roo et al., 2010; Sicuro and Luzzana, 2016). Despite the importance of almaco jack, few genetic studies have been published relative to other species in the genus, including $S$. 
dumerili (Risso 1810) (e.g. Gold and Richardson 1998; Šegvić-Bubić et al., 2016); S. Ialandi Valenciennes 1833 (e.g. Miller et al., 2011; Premachandra et al., 2017; Purcell et al., 2015) and S. quinqueradiata Temminck and Schlegel 1845 (e. g. Ohara et al., 2003, 2005). Only two published studies on almaco jack exist, a characterization of the mitochondrial genome (Chen et al., 2016) and an assessment of the diversity at the three mitochondrial and eighth microsatellite loci from individuals sampled in the Mediterranean Sea and the eastern Atlantic Ocean (Šegvić-Bubić et al., 2016). Neither of these studies assessed genetic diversity for the purpose of delimitation of wild populations or stocks of almaco jack.

The distribution of almaco jack includes low latitudes of the Atlantic with individuals, likely vagrant, occasionally seen in the Mediterranean Sea (as suggested by Castriota et al., 2002 and Šegvić-Bubić et al., 2016), in the Pacific and the Indian Oceans (Robertson and Allen, 2015) in waters surrounding the equator. Almaco jack are pelagic and mainly oceanic in habit relative to their congeners (Castriota et al., 2002; Robertson and Allen, 2015) and, therefore, it is expected that the species has the capacity for long distance dispersal (gene flow). This study was designed to answer two basic questions: 1) how many genetic stocks of almaco jack exist in the Pacific and the western Atlantic Oceans, and 2) what the patterns of connectivity among those stocks are? To evaluate this, a portion of the mitochondrially-encoded cytochrome c oxidase subunit 1 gene (COI) and nuclear-encoded single nucleotides 
polymorphisms (SNPs) were characterized. The information reported here will help with the sustainable use of this wild genetic resource and will provide a genetic baseline for aquaculture and breeding programs.

\section{MATERIAL AND METHODS}

\section{Sampling collection}

This study complied with all ethical requirements of the Journal of Fish Biology and local authorities. Fin clips were collected from a total of 135 individual almaco jack in the Atlantic $(\mathrm{N}=40)$ and Pacific $(\mathrm{N}=95)$ oceans, from 2012 to 2018. The collecting sites were grouped into ten geographic samples (hereafter referred as localities); five of them in the eastern Pacific (EPA: EP1-EP5), two that includes the western and central Pacific samples (WPA and CPA, respectively) and three in the western Atlantic (WAT: AT7-AT9, Table 1, Figure 1). DNA was extracted using the modified salt extraction technique proposed by Sambrook et al. (1989). Since many tissues were supplied by fishermen or non-experts, initial species identification were made using cytochrome c oxidase subunit 1 (COI), widely used as a DNA barcode (Ward et al., 2009). For amplification of COI, the FishF1 and FishR1 (Ward et al., 2005) primer set was used following reaction conditions described in Ivanova et al. (2007). PCR products were purified and sequenced by Macrogen Sequencing Service, 
Korea. Sequences were blasted against NCBI and Barcode of Life databases to validate field identification.

\section{mtDNA}

\section{Genetic diversity and population structure}

A total of $147 \mathrm{COI}$ sequences (Table 2), 113 generated in this study and 34 available from BOLD systems (BIN BOLD: AAB9420, S1), were aligned using the ClustalW multiple sequence alignment program in Mega v7.0.21 (Kumar et al., 2016), then were trimmed to $564 \mathrm{pb}$. Genetic diversity was estimated as the number of haplotypes $(H)$, number of segregating sites $(S)$, haplotype diversity $\left(H_{\mathrm{d}}\right)$, and nucleotide diversity ( $\pi$ ) with DnaSP v6 (Rozas et al., 2017). To understand the relationships and spatial distribution of the haplotypes, two TSC haplotype networks (Clement et al., 2002) were constructed in PopART 1.7 (Leigh and Bryant, 2015), one that included $\mathrm{COI}$ sequences generated in this study and those downloaded from the BOLD, and the second that excludes the latter. Population genetic differences was evaluated with AMOVA analysis with different models of hierarchy and pairwise $\phi_{S T}$ in Arlequin 3.5 (Excoffier and Lischer, 2010).

\section{$n D N A$}

\section{Libraries and SNP calling}


Libraries were prepared following the 3RADseq methodology proposed by BayonaVásquez et al. (2019). Briefly, the technique modifies typical double-digest restriction site-associated DNA (ddRAD) sequencing (Peterson et al., 2012) by including a third restriction enzyme that recognizes and cleaves adapter dimer. Fifty $\mu$ l of DNA (50 $\mathrm{ng} / \mu \mathrm{l})$ from each individual was sent to the Georgia Genomics and Bioinformatics Core at the University of Georgia, and libraries were generated using Clal, Mspl and $\mathrm{BamHI}$ restriction enzymes and sequenced on the Illumina Hiseq 4000 platform.

Raw sequences were demultiplexed and trimmed to 140 bp using process_radtags function in Stacks v2.2 (Catchen et al., 2013), then the quality of sequences assessed with FastQC v0.11.7 (Andrews, 2010). To reduce uncertainty in SNP calling, reads were directly mapped to the S. rivoliana genome (GenBank accession number GCA_002994505) using the dDocent v.2.7.3 pipeline (Puritz et al., 2014) which was used to remove low-quality bases (Phred quality score threshold of 30) and map reads and genotype SNPs using default parameters and a depth of $6 \mathrm{X}$. To further reduce errors several filters were applied using VCFtools v.0.1.14 (Danecek et al., 2011). Putative loci with a minimum sequence quality of 30 , a minimum genotype call rate per locus of $70 \%$, a minor allele count of 3 , a minimum depth of 3 and a minimum minor allele frequency of 0.03 were retained. Only individuals with less than $40 \%$ missing data were retained. Other filters included were based on allele balance $(>0.25 y<0.75)$, quality/depth ratio, mapping quality ratio of reference and 
alternate alleles, properly paired status, and maximum depth, following recommendations of O'Leary et al. (2018). Finally, loci out of Hardy-Weinberg equilibrium as well as linked loci $\left(>0.8 R^{2}\right)$, identified using VCFtools, were removed and rad_haplotyper (Willis et al., 2017) was used to screen for and remove potential paralogs.

\section{Identification of neutral loci}

Three approaches were utilized to detect outlier loci (loci putatively under selection), an analysis of principal components (PCA), implemented in the PCAdapt package in R (Luu et al., 2017); the Bayesian modeling approach implemented in BayeScan 2.1 program (Foll, 2012), and BayeScEnv 1.1 program (De Villemereuil and Gaggiotti, 2015), as is recommended in the literature (Hoban et al., 2016; Tiffin and Ross-Ibarra, 2014). In order to avoid potential biases in analyses caused by loci under selection, all outlier loci were discarded, and only neutral loci retained for downstream analyses.

\section{Population genetic structure}

To identify genetic groups as putative populations, two approaches were followed. First discriminant analysis of principal components (DAPC) was executed using the R package Adegenet 2.1.1 (Jombart and Ahmed, 2011) to identify clusters that maximize between group variation and minimize within group variation. The analysis 
was informed a priori with locality information and the xvalDapc function was used to identify the correct number of principal components to retain. Second the Bayesian clustering method as implemented in Structure v2.3.4 (Pritchard et al., 2000) was utilized. This method assumes ancestry and allele frequency models and uses expectations of linkage disequilibrium and Hardy-Weinberg equilibrium to assign individuals to a predetermined number of groups (K). To fully explore population subdivision and avoid underestimation of populations, Structure analysis was run in a hierarchical manner to identify putative populations within groups inferred from previous runs (Pritchard et al., 2010; Vähä et al., 2007). Briefly, Structure was run using the admixture model and correlated allele frequencies, with 10,000 burn in and 100,000 MCMC steps, values of $K$ were set between 1-9 with ten replicate runs for each value of $K$. The program StrAuto (Chhatre and Emerson, 2017) that combines Structure analysis with Structure Harvester (Earl and VonHoldt, 2012) was used to infer the optimal $K$ value using the $\Delta K$ statistic (Evanno et al., 2005). Results were compiled and visualized using Clumpak (Kopelman et al., 2015).

A hierarchical AMOVA was then run and pairwise $F_{\mathrm{ST}}$ estimated between each locality using Arlequin v.3.5.1.3 (Excoffier and Lischer, 2010) with significance determined using 1,000 permutations and corrected with false discovery rate (FDR) method (Benjamini and Hochberg, 1995). An isolation by distance test (IBD) was 
performed to correlate geographical distance and genetic differentiation $\left(F_{S T}\right)$ among localities using Adegenet 2.1.1 (Jombart and Ahmed, 2011), with significance determined using 1,000 permutations. Geographic distances were obtained from coordinates of the centroids of each polygon and the Euclidean distance was estimated with a correction for the curvature of the Earth using ArcMap 10.5 (ESRI, 2013).

\section{Genetic diversity and relative migration}

Measure of within group variation were estimated for each detected genetic population and included rarefied allelic richness $\left(N_{\mathrm{A}}\right)$, Nei's expected $\left(H_{\mathrm{e}}\right)$ heterozygosity and inbreeding coefficient $\left(G_{i s}\right)$ in Hierfstat R package (Goudet, 2005). Friedman and Wilcoxon tests, implemented in Stats package in $R(R$ Development Core Team R, 2011), were used to test for significance differences in indices of genetic diversity between populations.

The estimation of long-term gene flow was carried out through directional genetic differentiation and relative migration $(r m)$ approach using the divMigrate function (Sundqvist et al., 2016) from the R-package diveRsity (Keenan et al., 2013). This method uses Nei's $G_{S T}$ to calculate the relative magnitude of migration by assessing the genetic differentiation between two populations and a hypothetical pool of migrants. Using this method, it is possible detect relative asymmetric migration if 
migration rates are larger in one direction than the other direction (Sundqvist et al., 2016). The test was executed using 10,000 bootstrap replicates for all pairs of localities.

\section{RESULTS}

mtDNA genetic diversity and population structure

Thirty-nine COI sequences were discarded due to low quality (36 from this study and three from BOLD), 25 polymorphic sites were identified defining 21 haplotypes. The haplotypes with the highest frequencies were Hap_6 (19.27\%) in the eastern Pacific (EPA) followed by Hap_2 (16.51\%) in the western Atlantic (WAT) and eastern Atlantic (EAT) and Hap_1 (13.76\%) that includes individuals captured in the Indian (IND), western Pacific (WPA), central Pacific (CPA), EPA, and Atlantic (WAT and EAT) oceanic regions (S2). Haplotype diversity ranged from 0.28 (WPA) to 0.93 (CPA) in Pacific, while in Atlantic $H_{d}$ ranged from 0.47 (AT9 in WAT) to 0.83 (EAT), and for Indian was 0.75 . Nucleotide diversity was variable across localities with a range of $\pi=0.04$ (WPA) to $\pi=0.53$ (EP1 in EPA, Table 2). The haplotype network showed four groups containing a single dominant haplotype with associated satellite haplotypes (haplogroups hereafter), the first included individuals from IND, WPA and CPA, the second haplogroup included individuals of IND, WPA, CPA, EAT and some individual from WAT, the third haplogroup included individuals from the EPA and one 
individual from the WAT (AT9, collected in Venezuela) and the fourth included only individual from the Atlantic (WAT and EAT) and was four mutational steps from the EPA haplogroup (Figure 2). When sequences from BOLD were discarded, the structure of haplotypic network was maintained (S3) but included only 16 haplotypes and 20 polymorphic sites. Results of AMOVA indicated that the component of molecular variance attributable to differences between groups was maximized when the localities were grouped as oceanic regions (WAT, CPA and EPA: $F_{C T}=0.413, p=$ 0.001, S4). After FDR correction, all pairwise estimate of $\phi_{\mathrm{ST}}$ between central and eastern Pacific localities were significant and estimates ranged from 0.460-0.505. Localities in the central Pacific were also significantly differentiated from localities in the Atlantic ( $\phi_{S T}=0.310$ to 0.559$)$ and eastern Pacific localities were significantly differentiated from localities in the Atlantic $\left(\phi_{S T}=0.259-0.508\right.$, Table 3). Comparison between localities within oceanic basins were non-significant consistent with the presence of three genetic groups distributed in different ocean basins.

\section{SNPs genotyping and identification of neutral loci}

More than one million raw sequences were obtained from each individual. After trimming and calling SNPs there were a total of 1,284,903 SNPs genotyped in 135 individuals. Initial filtering steps reduced the number to 36,189 SNPs of which 4,938 SNPs were present in $80 \%$ of individuals and $80 \%$ of localities. SNPs contained in the same fragment were called as a single contiguous haplotype. After removing loci 
that did not conform to the expectations of Hardy-Weinberg equilibrium, linked loci and potentially paralogous loci there was a total of 4,339 SNPs (S5). Twenty-two individuals were excluded during filtering (Table 1) and 661 SNPs removed because they were identified as loci putatively under selection by at least one of three methods (PCAdapt, BayeScan and BayeScEnv; S5). The final data set consisted of 113 individuals genotyped at 3,678 SNP-containing loci.

\section{SNPs and population genetic structure}

DAPC identified three groups $(K=3$, Figure 3a), considering 40 principal components (PC) and retaining eight discriminant functions (DF). The first two DFs explained $96.2 \%$ of the genetic variation (DF1 $=78.2 \%$, DF2= 18\%). The first group or putative population (Pacific-1) contained all individuals sampled in Hawaii (CPA) and Vietnam (WPA), the second contained all individuals from eastern Pacific from EP1 to EP5, and the last contained all individuals from western Atlantic (AT7-AT9). However, when the third DF (DF3= 1.8\%) was considered, individuals from EP1 formed a fourth cluster (Pacific-3) distinguishable from individuals from other eastern Pacific localities (Pacific-2; Figure 3b).

The first Structure analysis, which included all localities, revealed two groups based on $\Delta K(K=2$, Figure 4, S6). The first group included all individuals from eastern Pacific while, the second included individuals from western Atlantic (AT7-AT9) and western-central Pacific (WPA and CPA). A second Structure analyses was carried 
out on these two groups separately and indicated a $K=2$ for each group, Individuals from EP1 separated from the rest of the EPA localities, and individuals from CPA and WPA grouped separately from WAT localities. A third round of Structure analysis was performed for Atlantic group and EPA localities; however, the results suggest $K=1$ (Figure 4). Because clustering methods grouped the Vietnamese individual with CPA, it was included in the Pacific-1 population for downstream analyses.

Results of AMOVA indicated that the component of molecular variance attributable to differences between groups was maximized when the localities were grouped as geographic regions: WAT, $\mathrm{CPA}$ and $\mathrm{EPA}\left(\mathrm{F}_{\mathrm{CT}}=0.329, \mathrm{p}=0.002, \mathrm{~S} 4\right)$, rather than when the localities were placed in the four populations detected with clustering methods $\left(F_{C T}=0.264, p=0.001, S 4\right)$. However estimated fixation indices $\left(F_{S T}\right)$ between localities (Table 3) were significantly different than zero after FDR correction method when localities in different oceanic basins were compared ( $F_{S T}$ : 0.164-0.377), when localities in the EPA were compared to the CPA ( $F_{S T}: 0.329$ 0.357), and in the EPA when EP1 was compared with EP4 and EP5 ( $F_{S T}: 0.009$ and 0.012, respectively) and when EP3 was compared EP4 ( $\left.F_{S T}: 0.009\right)$. The Mantel test was not significant $\left(R^{2}=0.194, p=0.072, S 7\right)$.

\section{Genetic diversity and relative migration}


The genetic diversity was carried out considering four populations detected by clustering methods (Pacific-1, Pacific-2, Pacific-3 and Atlantic). Allelic richness $\left(N_{\mathrm{A}}\right)$ ranged from 1.291 (Pacific-1) to 1.381 (Pacific-3, Table 4). The expected heterozygosity $\left(H_{e}\right)$ ranged from of 0.184 (Pacific-1) to 0.240 (Pacific-3) and estimates of $G_{i s}$ ranged from 0.069 (Atlantic) to 0.077 (Pacific-2). The initial Friedman test indicated significant differences among populations for $N_{\mathrm{A}}, H_{e}$ and $G_{i s}(p<$ 0.001). The results of paired Wilcoxon test indicated significant differences in $N_{\mathrm{A}}$ and $H_{e}$ between groups, except between Pacific-3 and Pacific-2 ( $p>0.05$, S8). Estimates of $G_{\text {is }}$ were different between populations with exception of Pacific-3 with Atlantic ( $p=$ $0.861, \mathrm{~S} 8)$.

Relative migration networks (Figure 5) were consistent with the results of clustering analyses and estimated fixation indexes $\left(F_{S T}\right)$, showing high levels of relative migration rates among localities in the eastern Pacific $(r m>0.46, p<0.05)$ with intensity being greater towards EP1 $(m>0.79, \mathrm{p}<0.05)$, while migration between the eastern and central Pacific was effectively zero ( $m<0.07, p<0.05$, S9). In Atlantic Ocean, relative migration was also asymmetric with greater intensity from north to south $(r m>0.87, p<0.05$, Figure 5$)$. Low values were also found between Atlantic and central Pacific $(r m<0.20, p<0.05$, S9).

\section{DISCUSSION}


This study used mitochondrial and nuclear molecular markers with different evolutionary rates to assess for discrete genetic populations (demes or stock) of almaco jack in the Pacific and western Atlantic oceans. Population genetic analyses using each marker type identified the same three populations: 1) central Pacific (Pacific-1), 2) eastern Pacific (Pacific-2), and 3) western Atlantic (Atlantic) (S4). In addition, analyses using SNPs identified hierarchal structuring, with EP1 in the eastern Pacific resolved as a fourth genetic population (Pacific-3). Finally, two wellseparated mtDNA lineages were found in individuals in the Atlantic with no evidence of population structure recovered using either marker.

Analysis of nuclear-encoded SNP data indicated hierarchical structuring with the primary division between the eastern Pacific and the rest of the sampling. Estimates of differentiation between the eastern Pacific and all other samples were high for both marker types $\left(\Phi_{\mathrm{ST}}: 0.259-0.508 ; F_{\mathrm{ST}}: 0.329-0.377\right)$ and only one mtDNA haplotype was shared among the three oceanic regions (Hap_1, Table 2). In addition, estimates of long-term migration rates between the eastern Pacific and other oceanic regions was effectively zero $(r m<0.07, p<0.05)$. Taken together this indicates a relative isolation of the eastern Pacific from all other oceanic regions sampled in this study, a pattern that has also been observed in other pelagic and shore fishes, such as yellowtail S. Ialandi. Premachandra et al. (2017) and Swart et al. (2016) reported high genetic differentiation $\left(F_{S T}=0.47\right)$ between $S$. Ialandi 
individuals distributed in Japan and Mexico, although this species migrates long distances (> 2,000 km, Gillanders et al., 2001). Likewise, species with high dispersal capacity such as the silky shark Carcharhinus falciformis (Bibron 1839) (GalvánTirado, et al., 2013) and yellowfin tuna Thynnus albacares (Bonnaterre 1788) (Barth et al., 2017; Grewe et al., 2015; Ward et al., 1994) also show this pattern. Even though behaviours of the adults of pelagic species such as dispersal, fidelity to a geographical region and/or breeding areas, can impeded or facilitate gene flow, it is thought that larval movements influenced by ocean currents may determine dispersal capacity of and, therefore, the potential genetic exchange between geographically distant populations (Riginos and Victor, 2001). In the case of the eastern Pacific, it is isolated from the central-west Pacific by the Eastern Pacific Barrier $(4,000-7,000 \mathrm{~km})$ that arose 65 MYA (Rosen and Smith, 1988) and the Central Pacific Gyre, both known to restrict gene flow in marine species (Lal et al., 2017; Robertson et al., 2004; Spalding et al., 2012). The eastern Pacific is also isolated from the western Atlantic by the Isthmus of Panama that arose $\sim 3$ MYA (Coates and Obando, 1996; but see O'Dea et al., 2016 for a review on the controversy about this date).

The next level of structure was between the western Atlantic and central-western Pacific oceanic regions, whose differentiation values were less than $\left(F_{\mathrm{ST}}=0.178\right)$ either of the two as compared to the eastern Pacific $\left(F_{\mathrm{ST}}>0.346\right)$. This situation 
suggests a potential connection after closure of the Isthmus of Panama between the Atlantic and western Pacific populations around the southern tip of South Africa which was open in each interglacial period (Swart et al., 2015) event that caused radiation of species from the Indo-Pacific to the Atlantic and vice versa (Hou and Li, 2018). Alternatively, the Atlantic could have been colonized via the Tethys seaway which closed 12 MYA (Hou and Li, 2018).

Finally, structure was found within the eastern Pacific region, as clustering analyses using SNP data indicated that EP1 (Pacific-3) was diverged from the rest of the eastern Pacific. However, analyses of COI failed to resolve these differences. Given that estimates of pairwise divergence were low but significant $\left(F_{\mathrm{ST}}<0.012, \mathrm{p}<0.05\right)$ between EP1 and the two southern most samples from the eastern Pacific (EP4 and EP5), it may be that EP1 has only recently begun to diverge. Estimates of long-term migration in the eastern Pacific indicated relatively high levels of historical connectivity $(r m>0.79)$ with higher migration from south to north (Figure 5$)$, consistent with the premise that eastern Pacific populations originated recently from a region of high gene flow (Hedrick, 2011). Given that some genetic populations are made up of samples collected over a period of time (Pacific-2 and Pacific-3), it is possible that they have influenced the conformation of this genetic group. Low but significant F $_{\text {ST }}$ values indicate that Pacific-2 collected in 2013 and 2017 (EP2-EP5, see Table 1) has a temporal structure (S10), probably indicating population mix, no 
significant differences were observed in Pacific-3 collected in 2015 and 2016, suggesting that the population mix occurs in lapses of time greater than two years, a population mix due to a temporary structure has been observed in S. Ialandi (Sepulveda and Gonzalez, 2017), therefore, better sampling is required over time to confirm these results.

The magnitude of estimated $F_{\mathrm{ST}}$ values also suggests potential isolation by distance along the eastern Pacific coast, a pattern reported for a number of species with wide distributions including hake Merluccius productus (Ayres 1855) (García-De León et al., 2018); sardine and anchovy (Lecomte et al., 2004); and the brown smoothhound shark (Chabot et al., 2015) however, the Mantel test was non-significant. Though there are no obvious geographical barriers in this region, the environmental characteristics associated with the current of California create a transition between sub-tropical and sub-arctic water bodies (Spalding et al., 2012) that could promote genetic differentiation between northern and more southern populations in the eastern Pacific; such a dynamic has been suggested for yellowfin tuna T. albacares (Díaz-Jaimes and Uribe-Alcocer, 2006).

In the western Atlantic Ocean results from both data sets were consistent with single population (Table 3). It is important to note that samples were only obtained from the Gulf of Mexico, which is almost completely enclosed by insular and continental land masses (Spalding et al., 2012) and population structure between the Gulf and 
Atlantic Ocean, which is common in many marine species (e.g. S. dumerili, Gold and Richardson, 1998; Hargrove et al., 2018; Carcharhinus acronotus (Poey 1860), Portnoy et al., 2014), could not be assessed by this study. Although no tagging studies have been reported for almaco jack, it is a mainly oceanic species with high dispersal potential (Castriota et al., 2002; Robertson and Allen, 2015), a feature that would promote gene flow over large areas, as has been reported in wide-ranging species like wahoo Acanthocybium solandri (Cuvier 1832) (Garber et al., 2005).

An unexpected finding in this study was the presence of haplotypes from three independent haplogroups in the Atlantic. Several individuals from the WAT had haplotypes that belonged to a haplogroup that includes individuals from the central and western Pacific, while the rest of the individuals sampled in the WAT had haplotypes in the eastern Pacific haplogroup or the Atlantic haplogroup (Figure 2). One possible explanation for the pattern is the presence of sympatric cryptic species, indicated by the divergent haplogroup (Atlantic, Figure 2) that showed seven mutational steps from second haplogroup that contained Indo-Pacific and Atlantic individuals, and four steps from the eastern Pacific haplogroup. To test this idea the average genetic distance (Kimura-2 parameters) between the divergent Atlantic haplogroup and other almaco jack haplogroups was compared to the average genetic distance between species in the genus Seriola (see supplementary material S11, S12, S13). The average genetic distance among species was 0.106 (S11), 
while the average genetic distance between haplogroups and the Atlantic haplogroup was 0.012 (S13). According to Ward and Holmes (2007) the average genetic distance for $\mathrm{COI}$ gene between congeneric marine fishes is approximately $10 \%$, consistent with the distance between species of Seriola presented here but not between haplogroups and, therefore, it seems unlikely that the Atlantic haplogroup represents a cryptic species.

Another mechanism that could account for divergent haplogroups within the Atlantic is secondary contact, a pattern characterized by the presence of shared haplotypes in different geographic locations caused by admixture between populations after long periods of geographic isolation (Avise, 2000). Colonization, isolation and recolonization of the Atlantic seems to be a common phenomenon in marine species and has occurred in a variety of taxa, across levels of biological organization (e.g. species of hydroids: Moura et al., 2019; species of surgeonfish within the genus Acanthurus, Siqueira et al., 2019; within species, Carcharhinus plumbeus (Nardo 1827), Portnoy et al., 2010). For many taxa the closure of the Tethys Sea (50-12 MYA) isolated the Atlantic and the Mediterranean Sea from the Indo-West Pacific, and changing current regimes led to transatlantic colonization predominately from east to west through tropical waters (Hou and Li, 2018). However, secondary colonization/contact could still occur from the eastern Pacific prior to the formation of the Isthmus of Panama (Lessios, 2008) or from the Indian Ocean during periodic 
slowing/warming of the Benguela current associated with recent ice ages (Hou and $\mathrm{Li}$, 2018). From the equation $d=2 u t(t=d / 2 u$, Arbogast et al., 2002) an approximate value of the temporal divergence between the most divergent haplogroups was calculated; resulting in an interval of 652 thousand generations (fast mutation) and 1.3 million generations (slow mutation), taken 5 years for the first sexual maturity (obtained from other species of the Seriola genus, FAO, 2016), the divergence time interval it would be between 3.2 to 6.5 million years, similar to those reported by Swart et al. (2015) 10 (Cl 1-12) MYA. The results of SNP analyses in this study are consistent with the individuals from WAT and Indo-Pacific being more closely related than either is to the EPA, suggesting that the Atlantic was colonized from an IndoPacific lineage (Figure 4, Table 3). This would indicate that patterns seen in mtDNA are likely the result of secondary contact occurring between the EPA and WAT oceanic regions through the Isthmus of Panama.

\section{Management implications}

This study highlights the complexity of identifying the genetic structure of pelagic species, even at world-wide scales. Because almaco jack is a species with high potential for worldwide aquaculture (Roo et al., 2010), knowledge about patterns of genetic diversity and levels of differentiation is a basic need for increased biosecurity (e.g. individual scape, diseases), allows for the traceability of seafood and identification of fish coming from farms, and conservation of wild stocks (Bernatchez 
et al., 2017). In Mexico the cultivation of almaco jack occurs in mariculture systems, however, during initial phases some farmers used individuals from Hawaii (Pacific-1 population) (Quiñones-Arreola et al., 2015). According to this study, that population is highly differentiated from eastern Pacific populations (Pacific-2 and Pacific-3). The translocations of individuals belonging to genetically differentiated populations represents a risk, because admixture could negatively impact local genetic pools by bringing in mal-adapted variants (Bernatchez et al., 2017). The information obtained in this study responds to the objectives of the Convention on Biological Diversity by providing data about genetic diversity in almaco jack that can be applied to sustainable use of biological diversity in situ and to regulate, manage or control the risks associated with the use organisms in aquaculture settings (United Nations, 1992). The findings here provide a reference for further evaluation population structure at global oceans to help fishery management and aquaculture developments to preserve genetic diversity. 


\section{ACKNOWLEDGMENTS}

We thank Neil Sims (Kampachi Farms LLC), Dr. Kang-Ning Shen (Aquatic Technology Laboratories, Agricultural Technology Research Institute, Taiwan), F. Infante, F. Valiente,

L. Getino, and J. M. Martinez Brown (CIAD) for collecting and donation of some specimen. We would like to thank, R. Vázquez and K. Vázquez (CIBNOR), D. Hendrickson (University of Texas at Austin), A. Fields (Texas A\&M University) and N. Bayona for help and advices in bioinformatics analysis as well as access to computer servers. VMP thanks GenCon Lab members for their contributions and discussions on the results of this study.

\section{AUTHOR CONTRIBUTIONS}

VMP and FJGdL planned the project. VMP performed laboratory analysis, generation and data analysis. DSP, JDD, FVQ and FJGdL contributed to statistical analysis. CGT conducted laboratory analysis. DSP, ODD, FJGdL and JCPU contributed with sampling. All participated in the writing of the manuscript. 


\section{REFERENCES}

1. Andrews, S. (2010). FastQC: A Quality Control Tool for High Throughput Sequence Data. Babraham Bioinformatics. Available at http://www.bioinformatics.babraham.ac.uk/ projects/fastqc.2010 (last accessed 28 February 2019).

2. Avise, J. C. (2000). Phylogeography: the history and formation of species. Harvard University Press.

3. Arbogast, B. S., Edwards, S. V., Wakeley, J., Beerli, P., \& Slowinski, J. B. (2002). Estimating divergence times from molecular data on phylogenetic and population genetic timescales. Annual review of Ecology and Systematics, 33, 707-740.

4. Barth, J. M. I., Damerau, M., Matschiner, M., Jentoft, S., \& Hanel, R. (2017). Genomic differentiation and demographic histories of Atlantic and Indo-Pacific yellowfin tuna (Thunnus albacares) populations. Genome Biology and Evolution, 9, 1084-1098.

5. Bayona-Vásquez, N. J., Glenn, T. C., Kieran, T. J., Pierson, T. W., Hoffberg, S. L., Scott, P. A., ... Faircloth, B. C. (2019). Adapterama III: Quadruple-Indexed, Double/Triple-Enzyme RADseq Libraries (2RAD/3RAD). PeerJ, 7, e7724.

6. Benjamini, Y., \& Hochberg, Y. (1995). Controlling the false discovery rate: a practical and powerful approach to multiple testing. Journal of the Royal Statistical Society: Series B, 57, 289-300.

7. Bernatchez, L., Wellenreuther, M., Araneda, C., Ashton, D. T., Barth, J. M. I., Beacham, T. D., ... Withler, R. E. (2017). Harnessing the power of genomics to secure the future of seafood. Trends in Ecology and Evolution, 32, 665-680.

8. Castriota, L. (2002). First record of Seriola rivoliana Cuvier, 1833 in the Mediterranean. Journal of Fish Biology, 60, 486-488.

9. Catchen, J., Hohenlohe, P. A., Bassham, S., Amores, A., \& Cresko, W. A. (2013). Stacks: an analysis tool set for population genomics. Molecular Ecology, 22, 31243140 .

10. Chabot, C. L., Espinoza, M., Mascareñas-Osorio, I., \& Rocha-Olivares, A. (2015). The effect of biogeographic and phylogeographic barriers on gene flow in the brown smoothhound shark, Mustelus henlei, in the northeastern Pacific. Ecology and Evolution, 5, 1585-1600.

11. Chen, Z., Li, Y., Liang, P., \& Li, M. (2016). The complete mitochondrial genome of longfin yellowtail S. rivoliana (Perciformes: Carangidae). Mitochondrial DNA, 27, 3385-3386. 
12. Chhatre, V. E., \& Emerson, K. J. (2017). StrAuto: automation and parallelization of STRUCTURE analysis. BMC Bioinformatics, 18, 1-11.

13. Clement, M., Snell, Q., Walke, P., Posada, D., \& Crandall, K. (2002). TCS: estimating gene genealogies. In Proc 16th Int Parallel Distrib Process Symp p. 2:184.

14. Coates, A. G., \& Obando, J. A. (1996). The geologic evolution of the Central American Isthmus. In J. Jackson, A. Budd \& A. Coates (Eds), Evolution and Environment in Tropical America (pp. 21-56). Chicago, University of Chicago Press.

15. Danecek, P., Auton, A., Abecasis, G., Albers, C. A., Banks, E., DePristo, M. A., ... Durbin, R. (2011). The variant call format and VCFtools. Bioinformatics, 27, 21562158.

16. De Villemereuil, P., \& Gaggiotti, O. E. (2015). A new FST-based method to uncover local adaptation using environmental variables. Methods in Ecology and Evolution, 6, 1248-1258.

17. Díaz-Jaimes, P., \& Uribe-Alcocer, M. (2006). spatial differentiation in the eastern Pacific yellowfin tuna revealed by microsatellite variation. Fisheries Science, 72 , 590-596.

18. Earl, D. A., \& VonHoldt, B. M. (2012). STRUCTURE HARVESTER: a website and program for visualizing STRUCTURE output and implementing the Evanno method. Conservation Genetics Resources, 4, 359-361.

19. Environmental Systems Research Institute (ESRI). (2013). ArcMap Desktop, Release 10.5. 1. Redlands, California.

20. Evanno, G., Regnaut, S., \& Goudet, J. (2005). detecting the number of clusters of individuals using the software STRUCTURE: a simulation study. Molecular Ecology, 14, 2611-2620.

21. Excoffier, L., \& Lischer, H. E. L. (2010). Arlequin suite ver 3.5: a new series of programs to perform population genetics analyses under Linux and Windows. Molecular Ecology Resources, 10, 564-567.

22. Foll, M. (2012). BayeScan v2.1. Ecology, 20, 1450-1462.

23. Food and Agriculture Organization of the United Nations (FAO). (2016). Cultured Aquatic Species Information Programme. Seriola dumerili. Cultured Aquatic Species Information Programme. Available at http://www.fao.org/fishery/culturedspecies/Seriola_dumerili/en (last accessed 29 May 2020).

24. Food and Agriculture Organization of the United Nations (FAO). (2018). The state of world fisheries and aquaculture. In Meeting the sustainable development goals 
pp. 1-230. Available at https://www.fao.org/publications (last accessed 18 July 2019).

25. Galván-Tirado, C., Díaz-Jaimes, P., García-De León, F. J., Galván-Magaña, F., \& Uribe-Alcocer, M. (2013). historical demography and genetic differentiation inferred from the mitochondrial DNA of the silky shark (Carcharhinus falciformis) in the Pacific Ocean. Fisheries Research, 147, 36-46.

26. Garber, A. F., Tringali, M. D., \& Franks, J. S. (2005). Population genetic and phylogeographic structure of wahoo, Acanthocybium solandri, from the western central Atlantic and central Pacific Oceans. Marine Biology, 147, 205-214.

27. García-De León, F. J., Galván-Tirado, C., Velasco, L. S., Silva-Segundo, C. A., Hernández-Guzmán, R., Barriga-Sosa, I. D. L. A., ... Cruz-Hernández, P. (2018). Role of oceanography in shaping the genetic structure in the North Pacific hake Merluccius productus. PLoS ONE, 13, e0194646.

28. Gillanders, B. M., Ferrell, D. J., \& Andrew, N. L. (2001). Estimates of movement and life-history parameters of yellowtail kingfish (Seriola lalandi): how useful are data from a cooperative tagging programme? Marine and Freshwater Research, 52, 179.

29. Gold, J. R., \& Richardson, L. R. (1998). Population structure in greater amberjack, Seriola dumerili, from the Gulf of Mexico and the western Atlantic Ocean. Fishery Bulletin, 96, 767-778.

30. Goudet, J. (2005). HIERFSTAT, a package for $\mathrm{R}$ to compute and test hierarchical f-statistics. Molecular Ecology Notes, 5, 184-186.

31. Grewe, P. M., Feutry, P., Hill, P. L., Gunasekera, R. M., Schaefer, K. M., Itano, D. G., ... Davies, C. R. (2015). Evidence of discrete yellowfin tuna (Thunnus albacares) populations demands rethink of management for this globally important resource. Scientific Reports, 5, 1-9.

32. Hargrove, J. S., Murie, D. J., Parkyn, D. C., Saarinen, E. V., \& Austin, J. D. (2018). mixing rates in weakly differentiated stocks of greater amberjack (Seriola dumerili) in the Gulf of Mexico. Genetica, 146, 393-402.

33. Hedrick, P. W. (2011). Genetics of Populations, 4th ed. Jones and Bartlett Publishers.

34. Hoban, S., Kelley, J. L., Lotterhos, K. E., Antolin, M. F., Bradburd, G., Lowry, D. B., ... Whitlock, M. C. (2016). Finding the genomic basis of local adaptation: pitfalls, practical solutions, and future directions. The American Naturalist, 188, 379-397.

35. Hou, Z., \& Li, S. (2018). Tethyan changes shaped aquatic diversification. Biological Reviews, 93, 874-896. 
36. Ivanova, N. V., Zemlak, T. S., Hanner, R. H., \& Hebert, P. D. N. (2007). Universal primer cocktails for fish DNA barcoding. Molecular Ecology Notes, 7, 544-548.

37. Jombart, T., \& Ahmed, I. (2011). Adegenet 1.3-1: new tools for the analysis of genome-wide SNP data. Bioinformatics, 27, 3070-3071.

38. Keenan, K., McGinnity, P., Cross, T. F., Crozier, W. W., \& Prodöhl, P. A. (2013). diveRsity: an R package for the estimation and exploration of population genetics parameters and their associated errors. Methods in Ecology and Evolution, 4, 782788.

39. Kopelman, N. M., Mayzel, J., Jakobsson, M., Rosenberg, N. A., \& Mayrose, I. (2015). CLUMPAK: a program for identifying clustering modes and packaging population STRUCTURE inferences across K. Molecular Ecology Resources, 15, 1179-1191.

40. Kumar, S., Stecher, G., \& Tamura, K. (2016). MEGA7: Molecular evolutionary genetics analysis version 7.0 for bigger datasets. Molecular Biology and Evolution, 33, 1870-1874.

41. Lal, M. M., Southgate, P. C., Jerry, D. R., Bosserelle, C., \& Zenger, K. R. (2017). Swept away: ocean currents and seascape features influence genetic structure across the $18,000 \mathrm{~km}$ Indo-Pacific distribution of a marine invertebrate, the blacklip pearl oyster Pinctada margaritifera. BMC Genomics, 18, 66.

42. Lecomte, F., Grant, W. S., Dodson, J. J., Rodríguez-Sánchez, R., \& Bowen, B. W. (2004). Living with uncertainty: genetic imprints of climate shifts in east Pacific anchovy (Engraulis mordax) and sardine (Sardinops sagax). Molecular Ecology, 13, 2169-2182.

43. Leigh, J. W., \& Bryant, D. (2015). PopART: full-feature software for haplotype network construction. Methods in Ecology and Evolution, 6, 1110-1116.

44. Lessios, H. A. (2008). The great American Schism: divergence of marine organisms after the rise of the Central American Isthmus. Annual Review of Ecology, Evolution, and Systematics, 39, 63-91.

45. Luu, K., Bazin, E., \& Blum, M. G. B. (2017). PCAdapt: an R package to perform genome scans for selection based on principal component analysis. Molecular Ecology Resources, 17, 67-77.

46. Miller, P. A., Fitch, A. J., Gardner, M., Hutson, K. S., \& Mair, G. (2011). Genetic population structure of yellowtail kingfish (Seriola lalandi) in temperate Australasian waters inferred from microsatellite markers and mitochondrial DNA. Aquaculture, 319, 328-336.

47. Moura, C. J., Collins, A. G., Santos, R. S., \& Lessios, H. (2019). Predominant east to west colonizations across major oceanic barriers: insights into the 
phylogeographic history of the hydroid superfamily Plumularioidea, suggested by a mitochondrial DNA barcoding marker. Ecology and Evolution, 9, 13001-13016.

48. O'Dea, A., Lessios, H. A., Coates, A. G., Eytan, R. I., Restrepo-Moreno, S. A., Cione, A. L., ... Jackson, J. B. C. (2016). Formation of the Isthmus of Panama. Science Advances, 2, 1-12.

49. O'Leary, S. J., Puritz, J. B., Willis, S. C., Hollenbeck, C. M., \& Portnoy, D. S. (2018). These aren't the loci you'e looking for: principles of effective SNP filtering for molecular ecologists. Molecular Ecology, 3193-3206.

50. Ohara, E., Nishimura, T., Sakamoto, T., Nagakura, Y., Mushiake, K., \& Okamoto, N. (2003). Isolation and characterization of microsatellite loci from yellowtail Seriola quinqueradiata and cross-species amplification within the genus Seriola. Molecular Ecology Notes, 3, 390-391.

51. Ohara, E., Nishimura, T., Nagakura, Y., Sakamoto, T., Mushiake, K., \& Okamoto, N. (2005). Genetic linkage maps of two yellowtails (Seriola quinqueradiata and Seriola lalandi). Aquaculture, 244, 41-48.

52. Peterson, B. K., Weber, J. N., Kay, E. H., Fisher, H. S., \& Hoekstra, H. E. (2012). Double digest RADseq: an inexpensive method for de novo SNP discovery and genotyping in model and non-model species. PLOS ONE, 7, e37135.

53. Portnoy, D. S., Hollenbeck, C. M., Belcher, C. N., Driggers, W. B., Frazier, B. S., Gelsleichter, J., ... Gold, J. R. (2014). Contemporary population structure and postglacial genetic demography in a migratory marine species, the blacknose shark, Carcharhinus acronotus. Molecular Ecology, 23, 5480-5495.

54. Portnoy, D. S., McDowell, J. R., Heist, E. J., Musick, J. A., \& Graves, J. E. (2010). World phylogeography and male-mediated gene flow in the sandbar shark, Carcharhinus plumbeus. Molecular Ecology, 19, 1994-2010.

55. Premachandra, H. K. A., Lafarga-De la Cruz, F., Takeuchi, Y., Miller, A., Fielder, S., O'Connor, W., ... Knibb, W. (2017). Genomic DNA variation confirmed Seriola lalandi comprises three different populations in the Pacific, but with recent divergence. Scientific Reports, 7, 1-11.

56. Pritchard, J. K., Stephens, M., \& Donnelly, P. (2000). Inference of population structure using multilocus genotype data. Genetics, 155, 945-959.

57. Pritchard, J. K., Wen, X., \& Falush, D. (2010). Documentation for Structure software: version 2. 3. University of Chicago \& University of Oxford.

58. Purcell, C. M., Chabot, C. L., Craig, M. T., Martinez-Takeshita, N., Allen, L. G., \& Hyde, J. R. (2015). Developing a genetic baseline for the yellowtail amberjack species complex, Seriola lalandi sensu lato, to assess and preserve variation in 
wild populations of these globally important aquaculture species. Conservation Genetics, 16, 1475-1488.

59. Puritz, J. B., Hollenbeck, C. M., \& Gold, J. R. (2014). dDocent: a RADseq, variantcalling pipeline designed for population genomics of non-model organisms. PeerJ, 2, e431.

60. Quiñones-Arreola, M. F., Arcos-Ortega, G. F., Gracia-López, V., CasillasHernández, R., Weirich, C., Morris, T., ... Ibarra-Gámez, C. (2015). Reproductive broodstock performance and egg quality of wild-caught and first-generation domesticated Seriola rivoliana reared under same culture conditions. Latin American Journal of Aquatic Research, 43, 953-962.

61. R Development Core Team, R. (2011). R: A Language and Environment for Statistical Computing.

62. Riginos, C., \& Victor, B. C. (2001). Larval spatial distributions and other early lifehistory characteristics predict genetic differentiation in eastern Pacific blennioid fishes. Proceedings of the Royal Society B: Biological Sciences, 268, 1931-1936.

63. Robertson, D. R., \& Allen, G. R. (2015). Shorefishes of the Tropical Eastern Pacific: online information system. Available at https://www.biogeodb.stri.si.edu/sftep/en/pages (last accessed 13 August 2019).

64. Robertson, D. R., Grove, J. S., \& McCosker, J. E. (2004). Tropical Transpacific Shore Fishes. Pacific Science, 58, 507-565.

65. Roo, J., Grossi, E., Schuchardt, D., Socorro, J. A., Hernández-Cruz, C. M., Izquierdo, M. S., \& Fernández-Palacios, H. (2010). Potential of almaco jack Seriola rivoliana as a fast-growing species for European aquaculture diversification. Report of Aquaculture Europe Conference 2010. Available at https://www.researchgate.net/publication/267024778_potential_of_almako_jack_s eriola_rivoliana_as_a_fastgrowing_species_for_european_aquaculture_diversification (last accessed 28 February 2019)

66. Roo, J., Fernández-Palacios, H., Hernández-Cruz, C. M., Mesa-Rodríguez, A., Schuchardt, D., \& Izquierdo, M. (2014). First results of spawning and larval rearing of longfin yellowtail Seriola rivoliana as a fast-growing candidate for european marine finfish aquaculture diversification. Aquaculture Research, 45, 689-700.

67. Rosen, B. R., \& Smith, A. B. (1988). Tectonics from fossils? Analysis of reef-coral and sea-urchin distributions from late Cretaceous to Recent, using a new method. Geological Society, London, Special Publications, 37, 1: 275-306. 
68. Rozas, J., Ferrer-Mata, A., Sanchez-DelBarrio, J. C., Guirao-Rico, S., Librado, P., Ramos-Onsins, S. E., \& Sanchez-Gracia, A. (2017). DnaSP 6: DNA sequence polymorphism analysis of large data sets. Molecular Biology and Evolution.

69. Sambrook, J., Fritsch, E. F., \& Maniatis, T. (1989). Molecular cloning: a labortaroy manual, 2nd edn. Cold Spring Harbor Laboratory Press.

70. Secretaría de Agricultura, Ganadería, Desarrollo Rural, P. y A. (SAGARPA). (2017). Acuerdo por el que se dan a conocer las reglas de operación del programa de Fomento a la productividad pesquera y acuícola de la Secretaría de Agricultura, Ganadería, Desarrollo Rural, Pesca y Alimentación para el ejercicio 2018. In Diario Oficial de la Federación (pp. 1-98), México. Available at: http://www.dof.gob.mx/nota_detalle.php?codigo=5509790\&fecha=30/12/2017 (last accessed 03 December 2018).

71.Šegvić-Bubić, T., Marrone, F., Grubišić, L., Izquierdo-Gomez, D., Katavić, I., Arculeo, M., \& Lo Brutto, S. (2016). Two seas, two lineages: how genetic diversity is structured in Atlantic and Mediterranean greater amberjack Seriola dumerili Risso, 1810 (Perciformes, Carangidae). Fisheries Research, 179, 271-279.

72. Sepulveda, F. A., \& Gonzalez, M. T. (2017). Spatio - temporal patterns of genetic variations in populations of yellowtail kingfish Seriola lalandi from the south eastern Pacific Ocean and potential implications for its fishery management. Journal of Fish Biology, 90, 249-264.

73. Sicuro, B., \& Luzzana, U. (2016). The state of Seriola spp. other than yellowtail (S. quinqueradiata) farming in the world. Reviews in Fisheries Science and Aquaculture, 24, 314-325.

74. Siqueira, A. C., Bellwood, D. R., \& Cowman, P. F. (2019). Historical biogeography of herbivorous coral reef fishes: the formation of an Atlantic fauna. Journal of Biogeography, 46, 1611-1624.

75. Spalding, M. D., Agostini, V. N., Rice, J., \& Grant, S. M. (2012). Pelagic provinces of the world: a biogeographic classification of the world's surface pelagic waters. Ocean and Coastal Management, 60, 19-30.

76. Sundqvist, L., Keenan, K., Zackrisson, M., Prodöhl, P., \& Kleinhans, D. (2016). Directional genetic differentiation and relative migration. Ecology and Evolution, 6, 3461-3475.

77. Swart, B. L., von der Heyden, S., Bester-van der Merwe, A., \& Roodt-Wilding, R. (2015). Molecular systematics and biogeography of the circumglobally distributed genus Seriola (Pisces: Carangidae). Molecular Phylogenetics and Evolution, 93, 274-280. 
78. Swart, B. L., Bester-van der Merwe, A. E., Kerwath, S. E., \& Roodt-Wilding, R. (2016). Phylogeography of the pelagic fish Seriola lalandi at different scales: confirmation of inter-ocean population structure and evaluation of southern African genetic diversity. African Journal of Marine Science, 38, 513-524.

79. Tiffin, P., \& Ross-Ibarra, J. (2014). Advances and limits of using population genetics to understand local adaptation. Trends in Ecology and Evolution, 29, 673-680.

80. United Nations. (1992). Convention on Biological Diversity United Nations 1992. Available at: https://www.cbd.int/convention/articles/?a=cbd-08 (last accessed 26 September 2019).

81. Vähä, J. P., Erkinaro, J., Niemelä, E., \& Primmer, C. R. (2007). Life-history and habitat features influence the within-river genetic structure of Atlantic salmon. Molecular Ecology, 16, 2638-2654.

82. Ward, R. D., Elliott, N. G., Grewe, P. M., \& Smolenski, A. J. (1994). Allozyme and mitochondrial DNA variation in yellowfin tuna (Thunnus albacares) from the Pacific Ocean. Marine Biology, 118, 531-539.

83. Ward, R. D., Hanner, R., \& Hebert, P. D. N. (2009). The campaign to DNA barcode all fishes, FISH-BOL. Journal of Fish Biology, 74, 329-356.

84. Ward, R. D., \& Holmes, B. H. (2007). An analysis of nucleotide and amino acid variability in the barcode region of Cytochrome C Oxidase I (Cox1) in fishes. Molecular Ecology Notes, 7, 899-907.

85. Ward, R. D., Zemlak, T. S., Innes, B. H., Last, P. R., \& Hebert, P. D. N. (2005). DNA barcoding Australia's fish species. Philosophical Transactions of the Royal Society B: Biological Sciences, 360, 1847-1857.

86. Willis, S. C., Hollenbeck, C. M., Puritz, J. B., Gold, J. R., \& Portnoy, D. S. (2017). Haplotyping RAD loci: an efficient method to filter paralogs and account for physical linkage. Molecular Ecology Resources, 17, 955-965. 


\section{FIGURES}

Figure 1. Map of sampling localities (shaped polygons) of Seriola rivoliana distributed in western Pacific (WPA), central Pacific (CPA), eastern Pacific (EPA: EP1-EP5), western Atlantic (WAT: AT7-AT9), eastern Atlantic (EAT) and Indian Ocean (IND). Dots are sampling data of this study; squares represent data from BOLD systems.

Figure 2. TCS haplotype network diagram constructed using mitochondrial $\mathrm{COI}$ gene sequences (generated in this study and BOLD). Circles represent haplotypes and colors indicate oceanic regions: Indic ocean (IND), western Pacific (WPA), central Pacific (CPA), eastern Pacific (EPA: EP1-EP5), western Atlantic (WAT: AT7-AT9) and eastern Atlantic (EAT). Vertical stripes show mutational steps, squares denote the haplogroups detected.

Figure 3. Genetic groups of almaco jack individuals from western (WPA) and central Pacific (CPA), eastern Pacific (EPA: EP1-EP5) and western Atlantic (WAT: AT7-AT9) obtained of discriminant analysis of principal components (DAPC) for neutral dataset. Plot in (a) represent the first two discriminant functions (DF) while (b) corresponds to first and third DF.

Figure 4. Hierarchical Structure analysis. Eastern (EPA: EP1-EP5), central (CPA), western (WPA) Pacific and western Atlantic oceans (WAT: AT7-AT9).

Figure 5. Network showing the strength and direction of relative migration among localities into Pacific and Atlantic oceans.

\section{TABLES}

Table 1. Collecting sites of $S$. rivoliana in Pacific and Atlantic oceans. The sites were organized into ten localities (see text), for each site is reported the geographic coordinates, the year of collecting event, number of individuals collected $(\mathrm{N})$ and individuals removed due to quality filters $(M)$.

Table 2. Genetic diversity of mtDNA by oceanic region. N: total individuals from collected data, B: samples from BOLD systems public data, M: individuals removed, S: segregate sites, $\mathrm{H}$ : haplotypes, $\mathrm{H}_{\mathrm{d}}$ : haplotypic diversity and $\mathrm{m}$ : nucleotidic diversity, SD: standard deviation.

Table 3. Genetic differentiation estimated by paired values of $\phi_{S T}$ mtDNA data (below diagonal) and $\mathrm{F}_{\mathrm{ST}} \mathrm{nDNA}$ (above diagonal). These pairwise comparisons were made by sampling sites within the Pacific (CPA and EPA, EPA: EP1-EP5) and the western Atlantic (WAT: AT7-AT9). In bold significant values $(p<0.05)$ after false discovery rate (FDR) correction.

Table 4. Genetic diversity by population based on SNPs data: allelic richness $\left(N_{A}\right)$, expected heterozygosity $\left(H_{e}\right)$ as well as the inbreeding coefficient $\left(G_{i s}\right)$. In brackets standard deviation (SD) and confidence interval (Cl 95\%). 
Table 1

\begin{tabular}{|c|c|c|c|c|c|c|c|c|}
\hline $\begin{array}{l}\text { Oceanic } \\
\text { region }\end{array}$ & Locality & Collecting site & Country & Latitude & Longitude & Year & $\mathbf{N}$ & $\mathbf{M}$ \\
\hline \multirow{28}{*}{$\begin{array}{c}\text { Eastern } \\
\text { Pacific } \\
\text { (EPA) }\end{array}$} & \multirow[t]{3}{*}{ EP1 } & San Carlos, BCS & Mexico & 24.684 & -112.245 & 2016 & 3 & 1 \\
\hline & & \multirow[t]{2}{*}{ Cabo San Lucas, BCS } & \multirow[t]{2}{*}{ Mexico } & \multirow[t]{2}{*}{22.878} & \multirow[t]{2}{*}{-109.874} & $\begin{array}{l}2015, \\
2016\end{array}$ & 24 & \\
\hline & & & & & & Total & 27 & 1 \\
\hline & \multirow{4}{*}{ EP2 } & San Evaristo, BCS & Mexico & 24.909 & -110.692 & 2013 & 10 & 1 \\
\hline & & Isla Cerralvo, BCS & Mexico & 24.282 & -109.954 & 2017 & 2 & \\
\hline & & La Paz, BCS & Mexico & 24.194 & -110.36 & 2015 & 1 & \\
\hline & & & & & & Total & 13 & 1 \\
\hline & \multirow[t]{6}{*}{ EP3 } & \multirow{6}{*}{$\begin{array}{c}\text { Estero de San Carlos, } \\
\text { Sonora } \\
\text { Mazatlán, Sinaloa } \\
\text { Puerto Vallarta, } \\
\text { Jalisco } \\
\text { Manzanillo, Colima } \\
\text { Lázaro Cárdenas, } \\
\text { Michoacán }\end{array}$} & Mexico & 27.955 & -110.978 & 2013 & 1 & 1 \\
\hline & & & Mexico & 23.217 & -106.448 & 2015 & 4 & \\
\hline & & & Mexico & 20.639 & -105.317 & 2017 & 2 & 1 \\
\hline & & & Mexico & 19.064 & -104.373 & 2018 & 2 & \\
\hline & & & Mexico & 17.865 & -102.191 & 2013 & 2 & \\
\hline & & & & & & Total & 11 & 2 \\
\hline & \multirow[t]{9}{*}{ EP4 } & \multirow{4}{*}{$\begin{array}{c}\text { Zihuatanejo, Guerrero } \\
\text { Playa Angosta, } \\
\text { Guerrero } \\
\text { Playa Amacas, } \\
\text { Guerrero } \\
\text { Acapulco, Guerrero }\end{array}$} & Mexico & 17.608 & -101.574 & 2017 & 2 & \\
\hline & & & Mexico & 16.842 & -99.922 & 2017 & 2 & \\
\hline & & & Mexico & 16.843 & -99.887 & 2017 & 8 & 3 \\
\hline & & & Mexico & 16.814 & -99.889 & 2017 & 2 & 1 \\
\hline & & \multirow{5}{*}{$\begin{array}{c}\text { Acapulco, Guerrero } \\
\text { Punta Maldonado, } \\
\text { Guerrero } \\
\text { Salina Cruz, Oaxaca } \\
\text { Puerto Ángel, Oaxaca }\end{array}$} & Mexico & 16.799 & -99.89 & 2017 & 3 & 1 \\
\hline & & & Mexico & 16.306 & -98.604 & 2017 & 2 & 1 \\
\hline & & & Mexico & 16.122 & -95.216 & 2017 & 1 & \\
\hline & & & Mexico & 15.638 & -96.481 & 2017 & 1 & \\
\hline & & & & & & Total & 21 & 6 \\
\hline & \multirow[t]{6}{*}{ EP5 } & Isla Cabo Blanco & $\begin{array}{c}\text { Costa } \\
\text { Rica }\end{array}$ & 9.542 & -85.11 & 2014 & 1 & \\
\hline & & Piedra Bisan & $\begin{array}{l}\text { Costa } \\
\text { Rica }\end{array}$ & 8.374 & -83.408 & 2014 & 1 & \\
\hline & & Panamá & Panamá & 8.75 & -79.481 & 2017 & 8 & 2 \\
\hline & & La Macarena & Colombia & 5.732 & -77.319 & 2013 & 2 & \\
\hline & & Playita Mía & Ecuador & 0.95 & -80.708 & 2013 & 1 & \\
\hline & & & & & & Total & 13 & 2 \\
\hline \multirow{2}{*}{$\begin{array}{l}\text { Central } \\
\text { Pacific } \\
\text { (CPA) }\end{array}$} & CPA & Hawaii & USA & 20.359 & -155.391 & 2017 & 8 & \\
\hline & & & & & & Total & 8 & \\
\hline \multirow{2}{*}{$\begin{array}{l}\text { Western } \\
\text { Pacific } \\
\text { (WPA) }\end{array}$} & WPA & Taiwan & Taiwan & 23.137 & 121.598 & 2017 & 1 & 1 \\
\hline & WPA & Vietnam & Vietnam & 13.998 & 109.387 & 2015 & 1 & \\
\hline
\end{tabular}




\begin{tabular}{|c|c|c|c|c|c|c|c|c|}
\hline & & & & & & Total & 2 & 1 \\
\hline \multirow{22}{*}{$\begin{array}{c}\text { Western } \\
\text { Atlantic } \\
\text { (WAT) }\end{array}$} & AT7 & Florida & USA & 26.921 & -83.093 & 2013 & 3 & \\
\hline & & Cuba & Cuba & 23.004 & -82.874 & 2017 & 1 & \\
\hline & & Cuba & Cuba & 22.108 & -84.844 & 2017 & 1 & \\
\hline & & Cuba & Cuba & 22.436 & -84.538 & 2017 & 1 & \\
\hline & & & & & & Total & 6 & \\
\hline & AT8 & Veracruz-Tamaulipas & Mexico & 22.33 & -97.45 & 2016 & 2 & \\
\hline & & Tuxpan, Veracruz & Mexico & 21.01 & -97.26 & 2016 & 9 & 4 \\
\hline & & Veracruz & Mexico & 19.189 & -96.108 & 2017 & 3 & 3 \\
\hline & & & & & & Total & 14 & 7 \\
\hline & AT9 & Yucatán & Mexico & 23.333 & -87.133 & 2016 & 1 & \\
\hline & & Yucatán & Mexico & 23.33 & -87.5 & 2016 & 1 & 1 \\
\hline & & Yucatán & Mexico & 22.566 & -88.983 & 2016 & 2 & \\
\hline & & Yucatán & Mexico & 22.158 & -91.502 & 2016 & 1 & \\
\hline & & Telchac, Yucatán & Mexico & 21.373 & -89.266 & 2016 & 2 & \\
\hline & & $\begin{array}{c}\text { Puerto Progreso, } \\
\text { Yucatán }\end{array}$ & Mexico & 21.368 & -89.689 & 2016 & 1 & \\
\hline & & $\begin{array}{c}\text { Puerto Progreso, } \\
\text { Yucatán }\end{array}$ & Mexico & 21.324 & -89.694 & 2016 & 3 & \\
\hline & & $\begin{array}{c}\text { Puerto Progreso, } \\
\text { Yucatán }\end{array}$ & Mexico & 21.315 & -89.687 & 2016 & 4 & \\
\hline & & $\begin{array}{c}\text { Puerto Progreso, } \\
\text { Yucatán }\end{array}$ & Mexico & 21.293 & -89.669 & 2015 & 1 & 1 \\
\hline & & Sisal, Yucatán & Mexico & 21.207 & -90.035 & 2015 & 1 & \\
\hline & & $\begin{array}{l}\text { Puerto Juárez, } \\
\text { Quintana Roo }\end{array}$ & Mexico & 21.17 & -86.782 & 2013 & 2 & \\
\hline & & Isla Margarita & Venezuela & 11.082 & -63.764 & 2012 & 1 & \\
\hline & & & & & & Total & 20 & 2 \\
\hline
\end{tabular}

This article is protected by copyright. All rights reserved. 
Table 2

\begin{tabular}{|c|c|c|c|c|c|c|c|c|}
\hline Oceanic region & Locality & $\mathbf{N}$ & B & $\mathbf{M}$ & $S$ & $\mathbf{H}$ & $H_{d}(S D)$ & $\pi(S D)$ \\
\hline \multirow[t]{5}{*}{$\begin{array}{c}\text { Eastern Pacific } \\
\text { (EPA) }\end{array}$} & EP1 & 10 & 2 & 6 & 2 & $5,6,9$ & $\begin{array}{c}0.73 \\
( \pm 0.15)\end{array}$ & $\begin{array}{c}0.53 \\
( \pm 0.04)\end{array}$ \\
\hline & EP2 & 10 & 0 & 1 & 4 & $5,6,7,8$ & $\begin{array}{c}0.69 \\
( \pm 0.14)\end{array}$ & $\begin{array}{c}0.08 \\
( \pm 0.02)\end{array}$ \\
\hline & EP3 & 10 & 0 & 2 & 5 & $5,6,7,9,10$ & $\begin{array}{c}0.78 \\
( \pm 0.15)\end{array}$ & $\begin{array}{c}0.08 \\
( \pm 0.01)\end{array}$ \\
\hline & EP4 & 21 & 0 & 6 & 5 & $1,5,6,9,10,11$ & $\begin{array}{c}0.81 \\
( \pm 0.06)\end{array}$ & $\begin{array}{c}0.06 \\
( \pm 0.01)\end{array}$ \\
\hline & EP5 & 13 & 2 & 7 & 2 & $6,9,10$ & $\begin{array}{c}0.67 \\
( \pm 0.12)\end{array}$ & $\begin{array}{c}0.05 \\
( \pm 0.01)\end{array}$ \\
\hline \multirow{5}{*}{$\begin{array}{c}\text { Central Pacific } \\
\text { (CPA) } \\
\text { Western Pacific } \\
\text { (WPA) } \\
\text { Nestern Atlantic } \\
\text { (WAT) }\end{array}$} & CPA & 8 & 6 & 0 & 9 & $1,12,13,14,15,16,18,19,20,21$ & $\begin{array}{c}0.93 \\
( \pm 0.05)\end{array}$ & $\begin{array}{c}0.08 \\
( \pm 0.04)\end{array}$ \\
\hline & WPA & 2 & 6 & 2 & 1 & 1,16 & $\begin{array}{c}0.28 \\
( \pm 0.19)\end{array}$ & $\begin{array}{c}0.04 \\
( \pm 0.02)\end{array}$ \\
\hline & AT7 & 6 & 4 & 5 & 5 & 1,2 & $\begin{array}{c}0.60 \\
( \pm 0.17)\end{array}$ & $\begin{array}{c}0.20 \\
( \pm 0.10)\end{array}$ \\
\hline & AT8 & 14 & 0 & 4 & 8 & $1,2,3,4$ & $\begin{array}{c}0.80 \\
( \pm 0.07)\end{array}$ & $\begin{array}{c}0.19 \\
( \pm 0.05)\end{array}$ \\
\hline & AT9 & 19 & 0 & 5 & 8 & $2,3,5$ & $\begin{array}{c}0.47 \\
( \pm 0.13)\end{array}$ & $\begin{array}{c}0.21 \\
( \pm 0.06)\end{array}$ \\
\hline $\begin{array}{l}\text { Eastern Atlantic } \\
\text { (EAT) }\end{array}$ & EAT & 0 & 4 & 0 & 6 & $1,2,4$ & $\begin{array}{c}0.83 \\
( \pm 0.22)\end{array}$ & $\begin{array}{c}0.16 \\
( \pm 0.06)\end{array}$ \\
\hline Indian (IND) & IND & 0 & 10 & 1 & 3 & $1,16,17,18$ & $\begin{array}{c}0.75 \\
( \pm 0.11)\end{array}$ & $\begin{array}{c}0.06 \\
( \pm 0.01)\end{array}$ \\
\hline & Total & 113 & 34 & 39 & 25 & 21 & $\begin{array}{c}0.69 \\
( \pm 0.17)\end{array}$ & $\begin{array}{c}0.14 \\
( \pm 0.13)\end{array}$ \\
\hline
\end{tabular}

This article is protected by copyright. All rights reserved. 
Table 3

\begin{tabular}{cccccccccc}
\hline & EP1 & EP2 & EP3 & EP4 & EP5 & CPA & AT7 & AT8 & AT9 \\
\hline EP1 & $*$ & 0.006 & 0.009 & $\mathbf{0 . 0 0 9}$ & $\mathbf{0 . 0 1 2}$ & $\mathbf{0 . 3 2 9}$ & $\mathbf{0 . 3 4 9}$ & $\mathbf{0 . 3 4 9}$ & $\mathbf{0 . 3 4 9}$ \\
EP2 & 0.015 & $*$ & 0.006 & 0.006 & 0.004 & $\mathbf{0 . 3 3 1}$ & $\mathbf{0 . 3 4 8}$ & $\mathbf{0 . 3 4 6}$ & $\mathbf{0 . 3 5 3}$ \\
EP3 & 0.065 & 0.077 & $*$ & $\mathbf{0 . 0 0 9}$ & 0.010 & $\mathbf{0 . 3 5 7}$ & $\mathbf{0 . 3 7 0}$ & $\mathbf{0 . 3 7 3}$ & $\mathbf{0 . 3 7 7}$ \\
EP4 & 0.023 & 0.019 & 0.039 & $*$ & 0.007 & $\mathbf{0 . 3 3 5}$ & $\mathbf{0 . 3 5 4}$ & $\mathbf{0 . 3 5 3}$ & $\mathbf{0 . 3 5 7}$ \\
EP5 & 0.100 & 0.125 & 0.018 & 0.059 & $*$ & $\mathbf{0 . 3 4 0}$ & $\mathbf{0 . 3 6 2}$ & $\mathbf{0 . 3 6 2}$ & $\mathbf{0 . 3 6 3}$ \\
CPA & $\mathbf{0 . 4 8 0}$ & $\mathbf{0 . 4 7 9}$ & $\mathbf{0 . 4 6 0}$ & $\mathbf{0 . 4 7 3}$ & $\mathbf{0 . 5 0 5}$ & $*$ & $\mathbf{0 . 1 7 8}$ & $\mathbf{0 . 1 6 9}$ & $\mathbf{0 . 1 6 4}$ \\
AT7 & $\mathbf{0 . 4 3 7}$ & $\mathbf{0 . 4 5 5}$ & $\mathbf{0 . 4 2 1}$ & $\mathbf{0 . 4 8 2}$ & $\mathbf{0 . 4 8 5}$ & $\mathbf{0 . 4 8 9}$ & $*$ & 0.015 & 0.012 \\
AT8 & $\mathbf{0 . 2 5 9}$ & $\mathbf{0 . 2 8 7}$ & $\mathbf{0 . 2 6 5}$ & $\mathbf{0 . 3 2 4}$ & $\mathbf{0 . 3 0 1}$ & $\mathbf{0 . 3 1 0}$ & 0.042 & $*$ & 0.008 \\
AT9 & $\mathbf{0 . 4 5 6}$ & $\mathbf{0 . 4 7 4}$ & $\mathbf{0 . 4 5 8}$ & $\mathbf{0 . 5 0 8}$ & $\mathbf{0 . 4 8 9}$ & $\mathbf{0 . 5 5 9}$ & 0.080 & 0.080 & $*$ \\
\hline
\end{tabular}

This article is protected by copyright. All rights reserved. 


\section{Table 4}

\begin{tabular}{|c|c|c|c|c|c|}
\hline $\begin{array}{c}\text { Oceanic } \\
\text { region }\end{array}$ & $\begin{array}{c}\text { Genetic } \\
\text { Population }\end{array}$ & $\mathbf{N}$ & $N_{A}( \pm S D)$ & $H_{e}(\mathrm{Cl} 95 \%)$ & $G_{i s}(\mathrm{Cl} 95 \%)$ \\
\hline \multirow[t]{2}{*}{$\begin{array}{l}\text { Eastern } \\
\text { Pacific } \\
\text { (EPA) }\end{array}$} & Pacific 3 & 26 & $\begin{array}{c}1.381 \\
( \pm 0.006)\end{array}$ & $\begin{array}{c}0.240 \\
(0.233-0.245)\end{array}$ & $\begin{array}{c}0.076 \\
(0.064-0.087)\end{array}$ \\
\hline & Pacific 2 & 47 & $\begin{array}{c}1.379 \\
( \pm 0.005)\end{array}$ & $\begin{array}{c}0.238 \\
(0.232-0.244)\end{array}$ & $\begin{array}{c}0.077 \\
(0.067-0.086)\end{array}$ \\
\hline $\begin{array}{l}\text { Central } \\
\text { Pacific } \\
\text { (CPA) }\end{array}$ & Pacific 1 & 9 & $\begin{array}{r}1.291 \\
( \pm 0.006)\end{array}$ & $\begin{array}{c}0.184 \\
(0.177-0.19)\end{array}$ & $\begin{array}{c}0.073 \\
(0.055-0.091)\end{array}$ \\
\hline $\begin{array}{l}\text { Western } \\
\text { Atlantic } \\
\text { (WAT) }\end{array}$ & Atlantic & 31 & $\begin{array}{c}1.323 \\
( \pm 0.006)\end{array}$ & $\begin{array}{c}0.196 \\
(0.193-0.206)\end{array}$ & $\begin{array}{c}0.069 \\
(0.057-0.080)\end{array}$ \\
\hline
\end{tabular}

This article is protected by copyright. All rights reserved. 


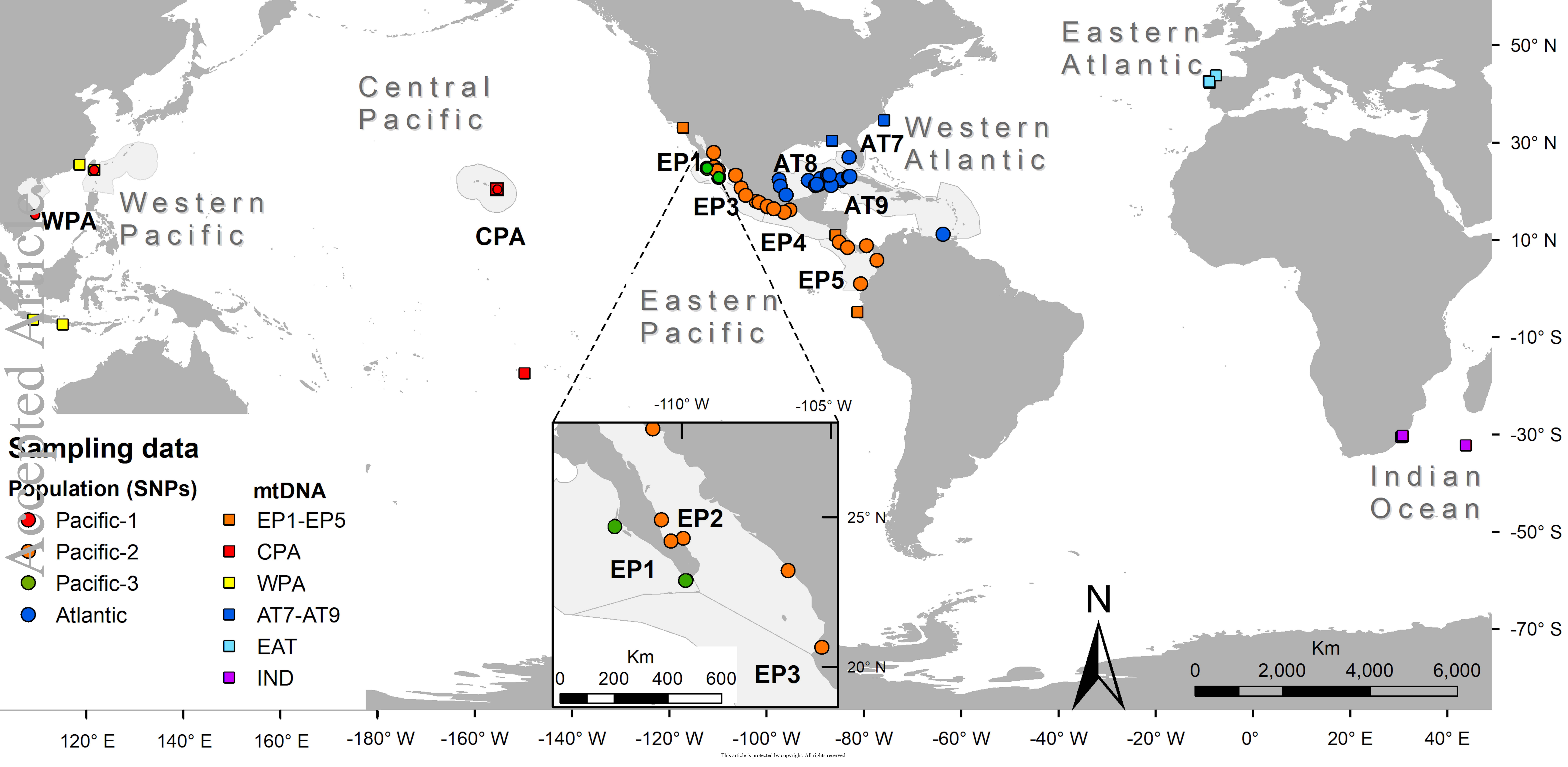





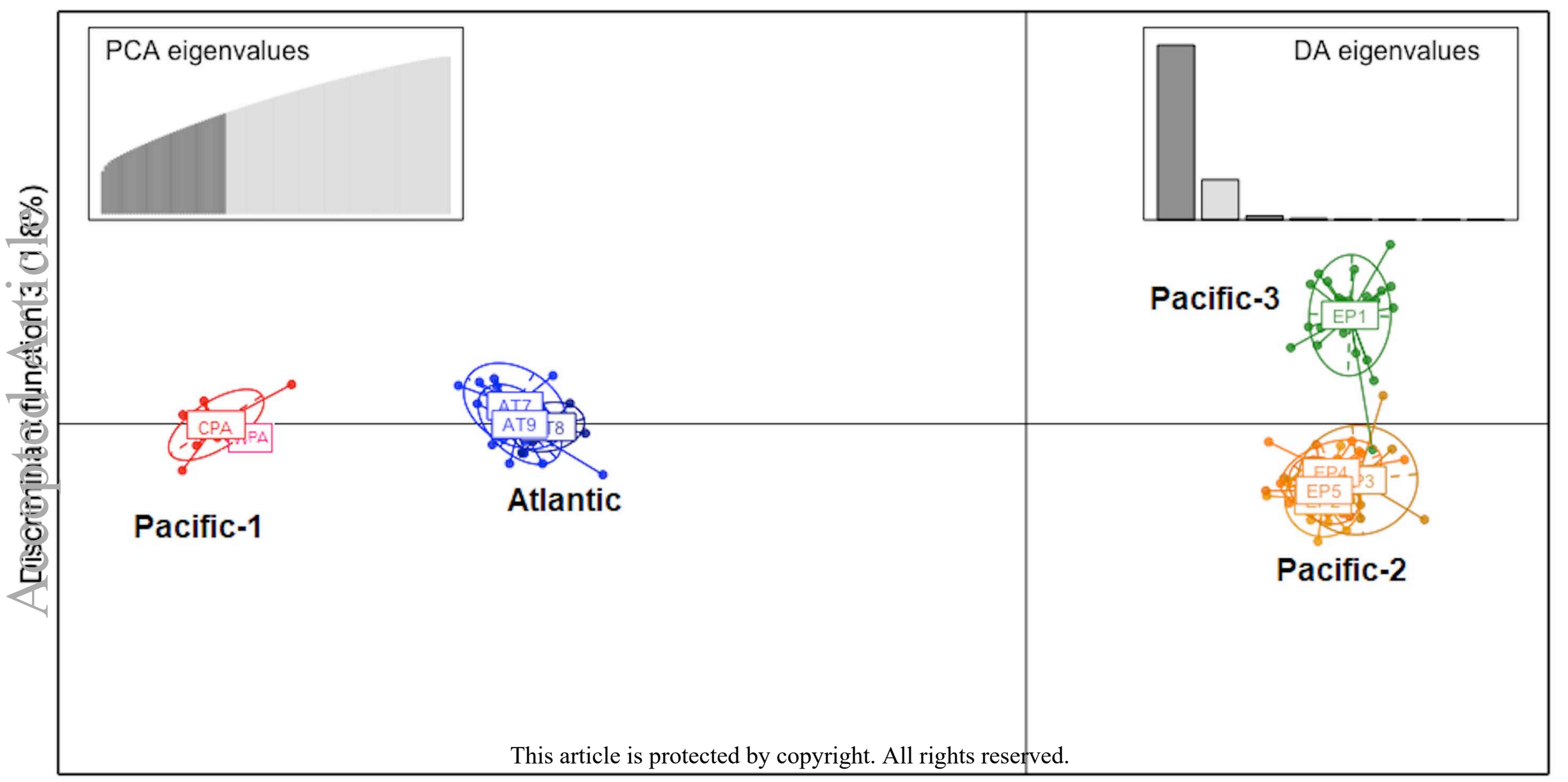

This article is protected by copyright. All rights reserved.

Discriminant function 1 (78.2\%) 


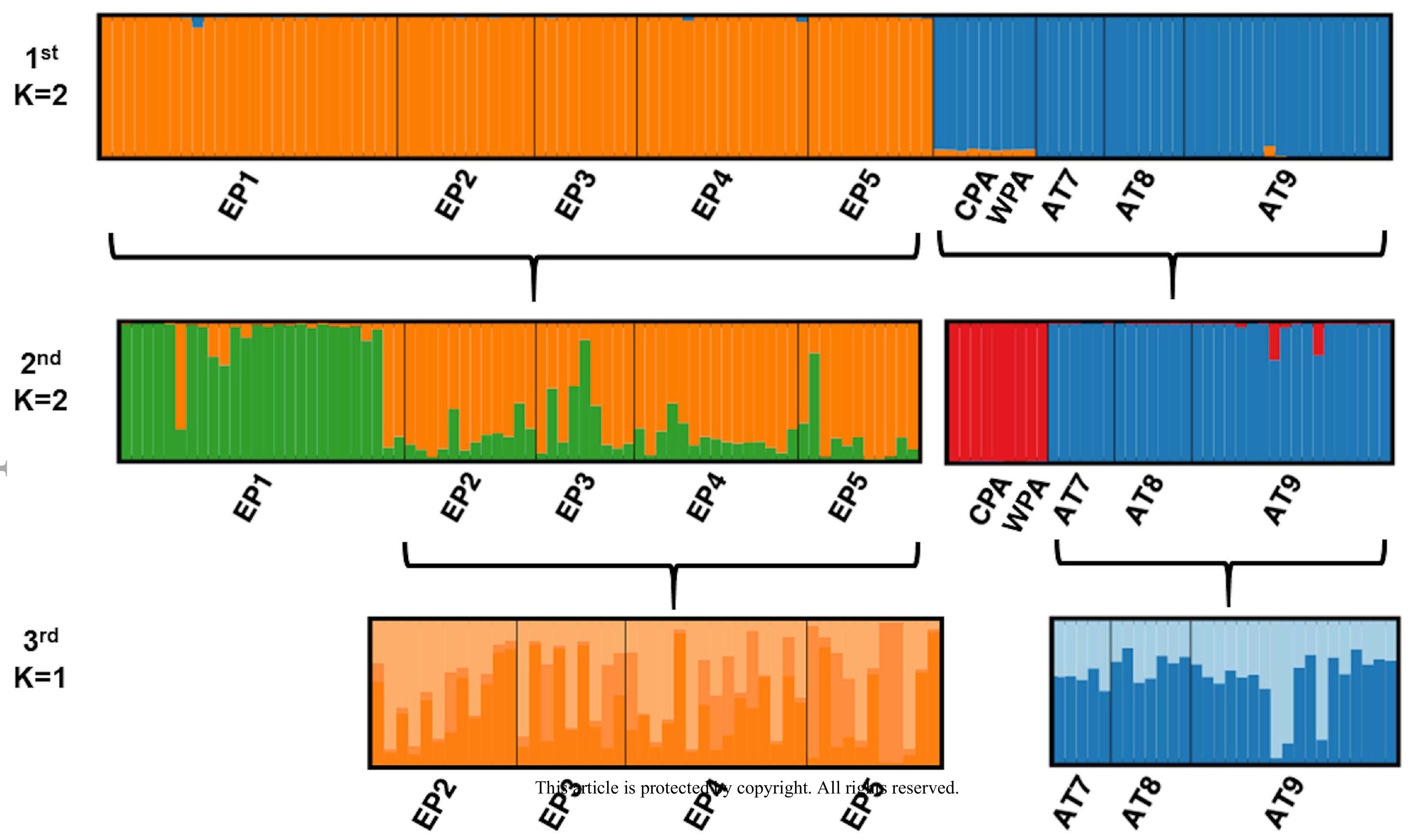


$\frac{1}{2}$

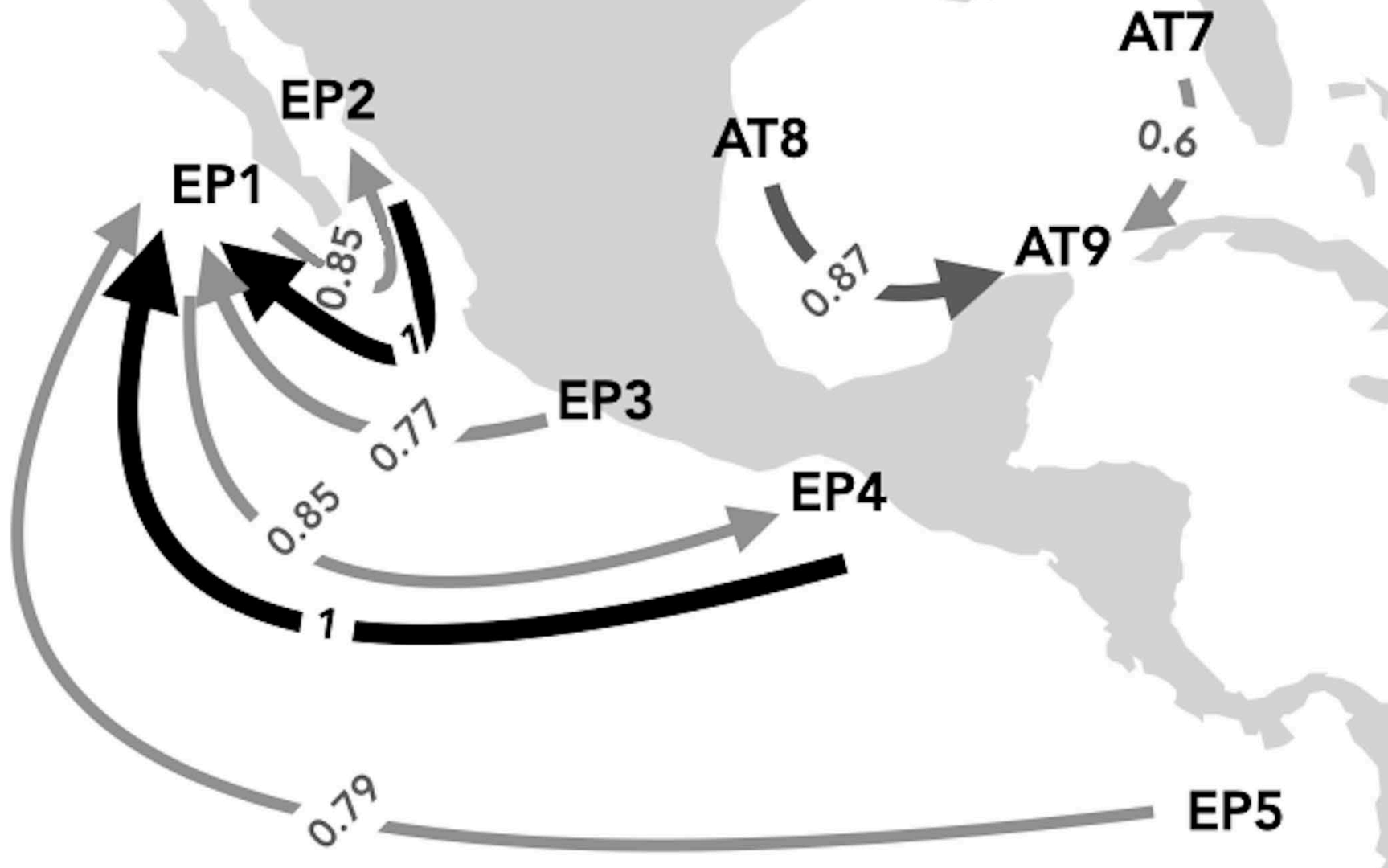

